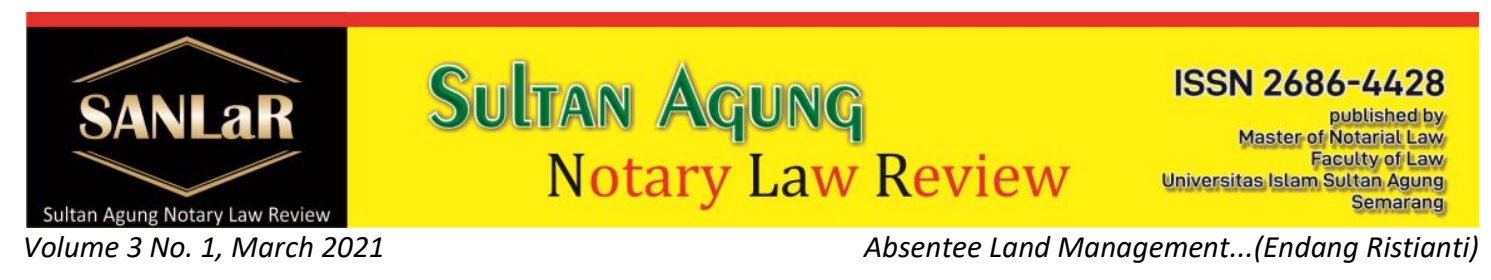

\title{
Absentee Land Management Policy by Civil Servants
}

\section{Endang Ristianti}

*) Student of Master of Notary Law, Faculty of Law, Universitas Islam Sultan Agung (UNISSULA) Semarang, E-mail: endang.ristianti@yahoo.com

$\left.{ }^{* *}\right)$ Lecturer of Master of Notary Law, Faculty of Law, Universitas Islam Sultan Agung (UNISSULA) Semarang

$\left.{ }^{* * *}\right)$ Lecturer of Master of Notary Law, Faculty of Law, Universitas Islam Sultan Agung (UNISSULA) Semarang

\begin{abstract}
This study aims to examine and analyze: 1) Implementation and Policy of Absentee Land Management by Civil Servants at the Land Office of Klaten Regency. 2) Implementation and Policy of Absentee Land Management by Civil Servants at the Klaten Regency Land Office. The approach method used in this research is the Normative approach. Normative legal research or library research is research that examines document studies, which uses various secondary data such as statutory regulations, court decisions, legal theory, and can be in the form of scholars' opinions. The research specification used is descriptive analytical. In this study, the data source consisted of primary data obtained by researchers through interviews and secondary data obtained through literature studies. Based on the results of the study, it can be concluded that: 1) Implementation of the implementation of absentee ownership of agricultural land obtained by Civil Servants provides opportunities for Civil Servants to be able to own the Absentee land. The legal instrument that regulates the ownership of Absentee land by Civil Servants/PNS is Government Regulation Number 4 of 1977 as described in the provisions of Article 2 paragraph (1), Article 2 paragraph (2), Article 2 paragraph (3) and Article 2 paragraph (4) Government Regulation Number 4 Of 1977. As for the implementation of absentee ownership of agricultural land in Klaten Regency, with the provision that a maximum distance of $8 \mathrm{~km}$ is stipulated for absentee land, if it exceeds $8 \mathrm{~km}$ then the implementation cannot be fulfilled. 2) Constraints in the Absentee Land Management Policy by Civil Servants at the Klaten Regency Land Office stem from community factors, namely the lack of legal awareness from the community Community life can run in an orderly and orderly manner, of course supported by an order so that life becomes orderly. Therefore, socialization plays an important role in the implementation of the Absentee Land Management Policy by Civil Servants at the Klaten Regency Land Office.
\end{abstract}

Keywords: Absentee; Civil Servants; Agricultural Land.

\section{Introduction}

Land is one of the production factors which is vital for human life and the development of a nation. The term land in our language is used in various meanings, so in use it 
needs to be defined in order to know in what meaning the term land is used. In the Land Law, the term "land" is used in a juridical sense, as a definition that has been legally defined by the Basic Agrarian Law.

The body of the earth and water and the space referred to do not belong to the holder of the land rights concerned, he is only allowed to use them. And even that there is a limit as stated in Article 4 paragraph (2) in the words: it is only necessary for the interests directly related to the use of the land, within the boundaries according to this law (UUPA) and other regulations which are more high. ${ }^{1}$

Agricultural land is very important in value in a nation. Due to the importance of agricultural land, agricultural land needs to be regulated so that it is not controlled on a large scale by only a few parties. Agricultural land is closely related to landreform.

In accordance with the above objectives and considering the agrarian situation and conditions in Indonesia at that time, the landrefrom program includes:

1. Limitation on the maximum area of land tenure,

2. Prohibition of owning land in what is called "absentee" or "guntai",

3. Retribution for lands that are more than the maximum limit, lands subject to the "absentee" prohibition, ex-Swapraja lands and State lands,

4. Regulations regarding the return and redemption of mortgaged lands,

5. Arrangement of agricultural land yield sharing agreements, and

6. Determination of the minimum area of ownership of agricultural land, accompanied by a prohibition to commit actions that result in the division of ownership of agricultural land into too small a share.

Exceptions for absentee ownership of land are further regulated in Article 2 paragraph (1). RegulationsGovernment Number 4 of 1977 which stipulates that since the entry into force of this Government Regulation, the exception of the provisions regarding the prohibition of owning agricultural land as a guntai (absentee) applies to civil servants as stipulated in Article 3 of Government Regulation Number 224 of 1961 (Gazette State Of 1961 Number 280) jo. Government Regulation Number 41 of 1964 (State Gazette of 1964 Number 112) up to a limit of 2/5 (two fifths) of the maximum land ownership for the Level II Region concerned shall also be treated for:

1. Retired civil servants

2. Widows of civil servants and widows of retired civil servants, as long as they do not remarry with a non-civil servant or retired civil servant.

Another exception is also found in Article 6 of Government Regulation Number 4 of 1977 which stipulates that: "a civil servant within 2 (two) years prior to retirement is allowed to buy agricultural land in a guntai (absentee) area of up to 2/5 (two fifths) of the maximum limit of land tenure for the Level II Region concerned".

\footnotetext{
${ }^{1}$ Harsono, Boedi. (2004). Hukum Agraria Indonesia. Jakarta: Djambatan. p.18
} 
The definition of a civil servant in Article 1 point 1 of Act No. 43 Of 1999 concerning Personnel Principles determines that a Civil Servant is every citizen of the Republic of Indonesia who has met the stipulated requirements, is appointed by an authorized official and is assigned other state duties and is paid based on Applicable Laws and Regulations. Civil servants consist of Civil Servants and members of the National Army and Members of the Indonesian National Police.

\section{Research methods}

The approach method used in this research is the Normative approach. Normative legal research or library research is research that examines document studies, which uses various secondary data such as statutory regulations, court decisions, legal theory, and can be in the form of scholars' opinions. ${ }^{2}$ The research specification used is descriptive analytical. Data collection was carried out by observation, interviews and literature study.In this research, an interactive analysis model is used, namely an analysis model that requires three components in the form of data reduction, data presentation, and conclusion/verification using a cycle process. ${ }^{3}$

\section{Result and Discussion}

\subsection{Implementation and Policy of Absentee Land Management by Civil Servants at the Klaten Regency Land Office}

The birth of the Basic Agrarian Law (UUPA) has a fundamental change in agrarian law in Indonesia, namely the realization of a uniform national land law. These changes are fundamental or fundamental, because both in terms of the structure of the legal instruments, regarding the basic conception, and their contents, must be in accordance with the interests of the Indonesian people and also fulfill their needs according to the demands of the times. ${ }^{4}$ The increasing rate of population growth and demand for residential land has resulted in rapid degradation of agricultural land. In Klaten District, absentee land ownership often occurs every year, both owned by ordinary citizens and civil servants (PNS).

A person may own agricultural land with certain limitations, meaning that the area of agricultural land needs to be limited because of the condition of the Indonesian people, who are mostly farmers who do not own land and work on other people's agricultural land to sustain their life. Absentee ownership of land is basically prohibited, because it is not in accordance with the principle of self-cultivation of agricultural land, but this prohibition is excluded from civil servants. Article 3 paragraph (4) Government Regulation Number 224 of 1961 stipulates that:

\footnotetext{
2 Soekanto, Soerjono and Sri Mamadji. (2009). Penelitian Hukum Normatif: Suatu Tinjauan Singkat. Jakarta: Raja Grafindo Persada. p.1

${ }^{3}$ HB Sutopo. (1998). Pengantar Penelitian Kualitatif: Dasar-dasar Teori dan Praktis. Surakarta: Pusat Penelitian Surakarta. p. 35

${ }^{4}$ Harsono, Boedi. (2003). Hukum Agraria Indonesia, Sejarah Pembentukan UUPA, Isi dan Pelaksanaanya, Ed. 1. Hukum Tanah Nasional. Jakarta: Djambatan. p. 1
} 
The provisions in paragraph (1) and paragraph (3) of this article do not apply to those who have land in the sub-district where they live or are sub-districts as meant in paragraph 2 of this article, who are carrying out State duties, fulfilling religious obligations, or having other special reasons which can be accepted by the Minister of Agrarian Affairs. For civil servants and military officials as well as their equivalent, who are carrying out State duties, the exception to this paragraph is limited to the ownership of agricultural land up to $2 / 5$ of the maximum area determined for the area concerned according to law. Number 56 Prp of 1960.

Exceptions to absentee ownership of land are further regulated in Article 2 paragraph (1) Government Regulation Number 4 of 1977 which stipulates that:

"Since the entry into force of this Government Regulation, the exception of the provisions regarding the prohibition of owning agricultural land in a guntai (absentee) which applies to civil servants as regulated in Article 3 of Government Regulation Number 224 of 1961 (State Gazette of 1961 Number 280) jo. Government Regulation Number 41 of 1964 (State Gazette Of 1964 Number 112) up to 7 limit 2/5 (two fifths) of the maximum land ownership for the Level II Region concerned shall also be treated for: ${ }^{5}$

1. Retired civil servants

2. Widows of civil servants and widows of retired civil servants as long as they do not remarry with a non-civil servant or retired civil servant. "Civil servants may own absentee land for two years before retirement and the area of land ownership is $2 / 5$ of the maximum area in the regency/city concerned.

Additional exemptions apply to retired civil servants and widows of retired civil servants. Another exception is also found in Article 6 of Government Regulation Number 4 of 1977 which stipulates that:

"A civil servant within 2 (two) years prior to retirement is allowed to buy agricultural land on an absentee basis up to 2/5 (two-fifths) of the maximum land tenure limit for the concerned Level II Region".

If a person owns agricultural land outside the district where he is located Live, except for civil servants who have received from inheritance, within 1 (one) year from the death of the heir, he is obliged to transfer his agricultural land to another person who resides in the sub-district where the agricultural land is located. Owners of agricultural land are not subject to this obligation if they change their residence in the sub-district where the agricultural land is located or the owner of the agricultural land changes their residence in the adjacent sub-district where the agricultural land is located.

Production sharing agreements (Production Sharing Business Rights) as land rights are given a temporary nature, in a short period of time and will be eliminated because it contains extortion characteristics, contains feudal characteristics, and is against the

\footnotetext{
${ }^{5}$ Article 3 Government Regulation Number 224 of 1961 concerning Implementation of Land Distribution and Compensation
} 
spirit of the LoGA. Regarding the calculation of profit sharing, according to Article 1 letter $c$ of the UUPA, what is meant by a production sharing agreement is an agreement with whatever name is differentiated between the land owner on one party and a person or legal entity on the other hand which in this law is called a cultivator based on an agreement where the cultivator permitted by the owner of the land to carry out agricultural business on the owner's land. So for agricultural land that is owned by guntai/absentee by Civil Servants (PNS), it is still permissible for him to be employed by means of sharing ${ }^{6}$

The implementation of the implementation of guntai agricultural land ownership (Absentee) obtained by Civil Servants, provides an opportunity for Civil Servants to be able to own the Absentee land. The legal instrument that regulates the ownership of Absentee land by Civil Servants/PNS is Government Regulation Number 4 of 1977 as described in the provisions of the Article below:

1. Article 2 paragraph (1) PP No. 4 of 1977. To stipulate that a person is not a civil servant or retired civil servant. Since the entry into force of this Government Regulation, the exemption from the provisions regarding the prohibition of owning agricultural land by guntai (absentee) which applies to civil servants as regulated in Article 3 of Government Regulation Number 224 of 1961 (LN of 1961 Number 280) jo. Government Regulation Number 41 of 1964 (LN of 1964 Number 112) up to a limit of $2 / 5$ (two fifths) of the maximum land ownership for the Level II Region concerned shall also be treated for: (a) Retired Civil Servants; and (b) Widows of Civil Servants and Widows of Retired Civil Servants as long as they do not remarry to a non-civil servant or retired civil servant.

2. Article 2 paragraph (2) Government Regulation Number 4 of 1977. The provisions referred to in paragraph (1) shall also apply to employees and retired employees who prior to the enactment of Act No. 8 of 1974 concerning Personnel Principles are equated with Civil Servants and at the time The enactment of this Law is already owning agricultural land by means of guntai.

3. Article 2 paragraph (3) Government Regulation Number 4 Of 1977. In the event that an employee or retired employee as referred to in paragraphs (1) and (2) passes away, the ownership of the agricultural land can be continued by the widow he left behind, as long as he is not married. again with a non-civil servant or retired civil servant.

4. Article 2 paragraph (4) Government Regulation Number 4 Of 1977. If the inherited land is left by a civil servant or his widow, the same applies to what is meant in paragraph (3) falls to the heirs who do not meet the requirements to own agricultural land as a result, then within 1 (one) year from the death of the owner, this share ownership must be terminated. ${ }^{7}$

Seeing the provisions of the article expressly, Civil Servants can own agricultural land in an absentee manner. However, this exemption applies as long as a person is still a Civil

\footnotetext{
${ }^{6}$ Interview with Mr. Mahmudi, Officer of the Klaten Regency Land Agency, November 10, 2020

7 Herdiyati, Chita. Kepemilikan Tanah Absentee Oleh Pegawai Negeri Sipil Berdasarkan Peraturan

Pemerintah Nomor 4 Tahun 1977, Faculty of Law-University of Airlangga Surabaya. p.952
} 
Servant. When he retires, the prohibition in question applies, in the sense that within the stipulated time the Civil Servant is obliged to reside in the District where the land is located or transfer ownership of the land to another party who may own it. In the general explanation point 3 of Government Regulation No. 4 of 1977 states that the reality shows that due to objective difficulties, it is not always easy for retired Civil Servants to fulfill their obligation to move from residence to near the land they own.

As for the implementation of absentee ownership of agricultural land in Klaten Regency, with the provision of a maximum distance of $8 \mathrm{~km}$, the provision for absentee land, if it exceeds $8 \mathrm{~km}$, the implementation cannot be fulfilled. The procedure regarding absentee land ownership in Klaten Regency is the same as the transfer of rights to agricultural land. Because from a material perspective, the whole regulations governing the prohibition of absentee/guntai land ownership were a product of around the 1960s, so that the thoughts at that time turned out to be in fact no longer in line with the conditions and needs of today's society.

\subsection{Constraints and Solutions in Absentee Land Management Policies by Civil Servants at the Klaten Regency Land Office}

The importance of the meaning of land for human life is that humans cannot be separated from the land at all. They live on the land and obtain food by utilizing the land. Everyone needs land because there are no activities or activities of people who do not need land. ${ }^{8}$

In the Implementation and Policy of Absentee Land Management by Civil Servants at the Klaten Regency Land Office, of course it cannot be separated from various obstacles, including:

1. Community factors, namely the lack of legal awareness of the community Social life can run in an orderly and orderly manner, of course supported by an order so that life becomes orderly. In society, order is, of course, indispensable, especially to create peace in human life, that peace means order (which is outward) and tranquility (which is inner). In this case, although the government has tried to prevent the occurrence of absentee/guntai ownership of agricultural land, this cannot be separated from the participation of the community to comply with existing regulations. This cannot be separated from the intention of someone who already knows about the regulations on the prohibition of absentee/guntai ownership of agricultural land, they deliberately violated these rules for their own economic gain. The absentee/guntai agricultural land that occurs due to trading under the hands, is generally produced by the owner as local residents as cultivators. This legal relationship is generally accepted and for the local population, especially smallholders, it is felt to be quite beneficial both from an economic and social/kinship perspective. Therefore, socialization plays an important role in the

${ }^{8}$ Siregar, Tampil Anshari. (2005). Mempertahankan Hak Atas Tanah. Medan: Multi Grafik Medan. p. 2 
implementation of the Absentee Land Management Policy by Civil Servants at the Klaten Regency Land Office.

2. Cultural Factors. In relation to the factors causing absentee/guntai soil from the cultural aspect, namely because of inheritance. This inheritance is a form of patterned behavior from humans themselves. Inheritance is actually a common legal event that occurs everywhere in every family, but this legal event is important to pay attention to in connection with the prohibition of absentee/guntai ownership of agricultural land, especially if the heir is located far outside the sub-district where the agricultural land is located. The absentee/guntai ownership of agricultural land can actually be avoided by moving the heirs to the sub-district where the inherited land is located, or the inherited land is transferred to residents who live in the sub-district.

According to the compiler, based on research at the Land Office in Klaten Regency, the implementation of the absentee implementation of the prohibition on agricultural land ownership is no longer effective to implement. Due to various considerations, the first is related to the absence of a database in the Klaten Regency Land Office. Second, lack of socialization or counseling from the Klaten Land Office for the community. Third, the lack of attention from the National Land Agency and the Klaten Regency National Land Office regarding land problems that arise in each region and the ignorance of the officials concerned about the condition of the land and the development of absentee agricultural land in Klaten district.

\section{Closing}

\subsection{Conclusion}

Based on the description above the conclusions in this study are:

1. The implementation of the implementation of guntai agricultural land ownership (Absentee) obtained by Civil Servants, provides an opportunity for Civil Servants to be able to own the Absentee land. The legal instrument that regulates the ownership of Absentee land by Civil Servants/PNS is Government Regulation Number 4 of 1977 as described in the provisions of Article 2 paragraph (1), Article 2 paragraph (2), Article 2 paragraph (3) and Article 2 paragraph (4) Government Regulation Number 4 of 1977. If the inherited land left by a civil servant or his widow, the same as what is meant in paragraph (3) falls to the heirs who do not meet the requirements to own agricultural land by guntai, then within 1 (one) year after the death of the owner, this partial ownership must be terminated. Seeing the provisions of the article expressly, Civil Servants can own agricultural land in an absentee manner. However, this exemption applies as long as a person is still a Civil Servant. When he retires, the prohibition in question applies, in the sense that within the stipulated time the Civil Servant is obliged to reside in the District where the land is located or transfer ownership of the land to another party who may own it. As for the implementation of absentee ownership of agricultural land in Klaten Regency, with the provision of a maximum distance of $8 \mathrm{~km}$, the provision for absentee 
land, if it exceeds $8 \mathrm{~km}$, the implementation cannot be fulfilled.

2. Constraints in the Absentee Land Management Policy by Civil Servants at the Klaten Regency Land Office stem from community factors, namely the lack of legal awareness of the community Community life can run in an orderly and orderly manner, of course supported by the existence of an order so that life becomes orderly. In society, order is, of course, indispensable, especially to create peace in human life, that peace means order (which is outward) and tranquility (which is inner). In this case, although the government has tried to prevent the occurrence of absentee/guntai ownership of agricultural land, this cannot be separated from the participation of the community to comply with existing regulations. This cannot be separated from the intention of someone who already knows about the regulations on the absentee/guntai prohibition of agricultural land ownership, they deliberately violate these regulations for their own economic gain. The absentee/guntai agricultural land that occurs due to trading under the hands, is generally produced by the owner as local residents as cultivators. This legal relationship is generally accepted and for the local population, especially smallholders, it is felt to be quite beneficial both from an economic and social/kinship perspective. Therefore, socialization plays an important role in the implementation of the Absentee Land Management Policy by Civil Servants at the Klaten Regency Land Office.

\subsection{Suggestion}

1. To see the facts obtained from this research, the compilers hope and want the Klaten Regency Land Office to pay attention to agricultural lands whose owners live outside the Bantul District, through routine and annual activities in the form of activities such as socialization and counseling.

2. The District Land Office should follow up on sanctions for violations of the prohibition on absentee land ownership, renewed and adjusted to the current developments in development progress and its implementation so that it is more emphasized.

\section{References}

Journal:

Herdiyati, Chita. Kepemilikan Tanah Absentee Oleh Pegawai Negeri Sipil Berdasarkan Peraturan Pemerintah Nomor 4 Tahun 1977, Faculty of LawUniversity of Airlangga Surabaya. p.952 Books:

[1] Harsono, Boedi. (2003). Hukum Agraria Indonesia, Sejarah Pembentukan UUPA, Isi dan Pelaksanaanya, Ed. 1. Hukum Tanah Nasional. Jakarta: Djambatan.

[2] Harsono, Boedi. (2004). Hukum Agraria Indonesia. Jakarta: Djambatan.

[3] HB Sutopo. (1998). Pengantar Penelitian Kualitatif: Dasar-dasar Teori dan Praktis. Surakarta: Pusat Penelitian Surakarta. 
[4] Siregar, Tampil Anshari. (2005). Mempertahankan Hak Atas Tanah. Medan: Multi Grafik Medan.

[5] Soekanto, Soerjono and Sri Mamadji. (2009). Penelitian Hukum Normatif: Suatu Tinjauan Singkat. Jakarta: Raja Grafindo Persada.

Interview:

Interview with Mr. Mahmudi, Officer of the Klaten Regency Land Agency, November 10, 2020

Regulation:

Article 3 Government Regulation Number 224 of 1961 concerning Implementation of Land Distribution and Compensation 